\title{
Unusual contents of a large incarcerated inguinal hernia
}

\author{
Kunal Patel, Lucy Francis, Balazs Fazekas, Jesse Panthagani
}

Department of General Surgery, Whipps Cross Hospital, London, UK

\section{Correspondence to} Dr Kunal Patel, Kunal. patel7366@gmail.com

Accepted 24 October 2014

\section{DESCRIPTION}

An 85 -year-old man presented with a 3-day history of profuse vomiting and lower abdominal pain. $\mathrm{He}$ was known to have a long-standing left inguinal hernia, which however had caused no pain or symptoms for many years.

On examination, his abdomen was soft, but to note was a marginally tender, large left inguinal scrotal hernia, which was irreducible (figure 1). A CT of the abdomen and pelvis was subsequently

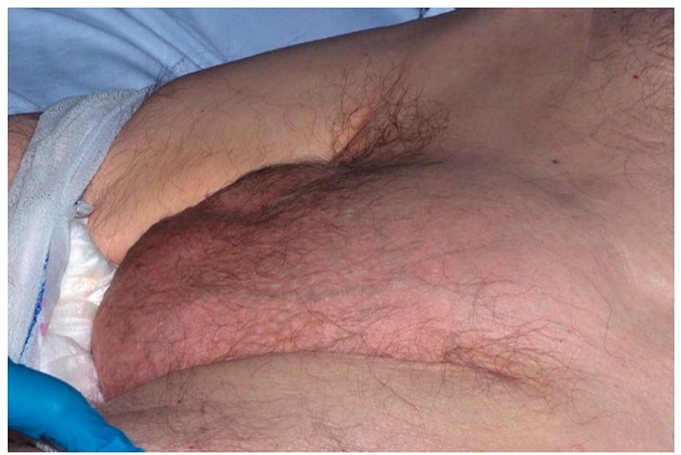

Figure 1 Large irreducible inguinal scrotal hernia.

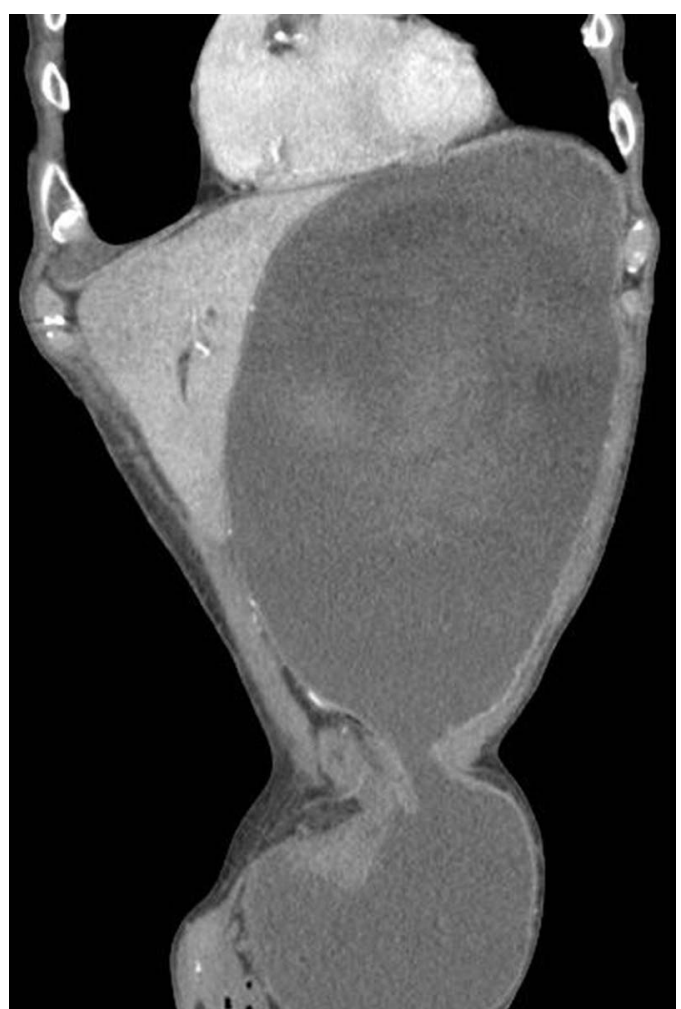

Figure 2 Large incarcerated left inguinal hernia containing a portion of the stomach resulting in very significant fluid-filled distension of the stomach.

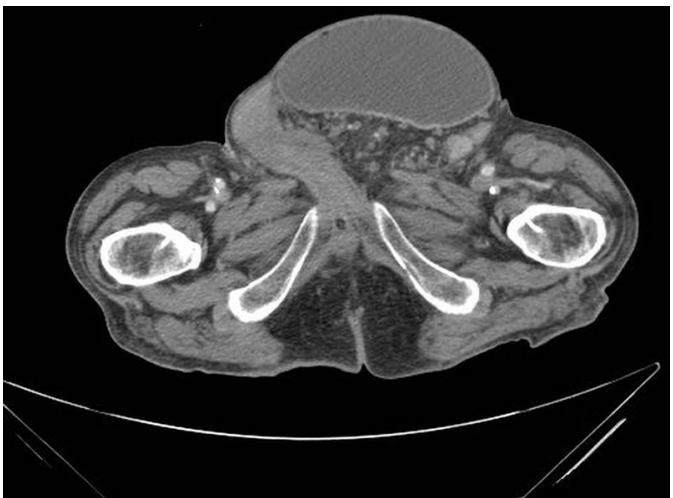

Figure 3 Loops of small bowel within the left inguinal hernia but there is no obstruction of the small bowel.

ordered which proved diagnostic, revealing a very large incarcerated left inguinal hernia containing a portion of the stomach, an uncommon finding.

The coronal sections from the CT scan demonstrate the extent of the gastric dilation spanning from the level of the diaphragm down into the leftsided inguinal hernia (figure 2). The axial section demonstrates the herniated stomach deviating the penile shaft; furthermore it shows small bowel contents inside the scrotum (figure 3 ).

A nasogastric tube was immediately passed which drained $6.5 \mathrm{~L}$ of fluid over $4 \mathrm{~h}$, and the patient was treated conservatively.

It is uncommon for the stomach to herniate through the inguinal canal; however, around 60 cases have been found in the literature, majority, prior to $1980 .^{1}$ It is possible, however, that the tension-free mesh repair, as described by Lichtenstein and Stoppa, led to surgical repair after this time. ${ }^{2}$

It is thought that long-standing traction on the greater omentum and its attachments may be responsible for the descent of the stomach into the hernial sac. ${ }^{3}$

\section{Learning points}

- Although now uncommon, it should be noted that a patient with symptoms of gastric outlet obstruction who has a large scrotal hernia, the possibility of a gastric herniation should be thought of.

- Radiological investigations are the gold standard and key for diagnosing such cases.

- An undiagnosed gastric outlet obstruction could lead to a perforated stomach. 
Contributors KP had managed to get the images as well as the clinical images and was involved in overlooking the content of the abstract. LF, JP and BF contributed to the history and writing the main abstract.

Competing interests None.

Patient consent Obtained.

Provenance and peer review Not commissioned; externally peer reviewed.

\section{REFERENCES}

1 Díaz Oller J, Medina Domínguez MT, Arcos Navarro A, et al. Stomach in inguinal-scrotal hernia. Rev Esp Enferm Dig 1997;89:325-8.

2 Sachs M, Damm M, Encke A. Historical evolution of inguinal hernia repairs. World J Surg 1997;21:218-23.

3 Padmanabhan Al, Lowenfels AB. Letter: an unusual hernia. JAMA 1976; 235:2813.

Copyright 2014 BMJ Publishing Group. All rights reserved. For permission to reuse any of this content visit http://group.bmj.com/group/rights-licensing/permissions.

BMJ Case Report Fellows may re-use this article for personal use and teaching without any further permission.

Become a Fellow of BMJ Case Reports today and you can:

- Submit as many cases as you like

- Enjoy fast sympathetic peer review and rapid publication of accepted articles

- Access all the published articles

- Re-use any of the published material for personal use and teaching without further permission

For information on Institutional Fellowships contact consortiasales@bmjgroup.com

Visit casereports.bmj.com for more articles like this and to become a Fellow 